\title{
Energy and Economic Evaluation of Thermal Comfort. The Case Study of the Hotel Residence L'Orologio
}

\author{
Carola Lingua ${ }^{1}$, Cristina Becchio ${ }^{1}$, Marta Carla Bottero ${ }^{2}$, Stefano Paolo Corgnati ${ }^{1}$, Federico \\ Dell'Anna ${ }^{2}$, Valentina Fabi ${ }^{1}$ \\ ${ }^{1}$ TEBE-IEEM Group, Energy Department (DENERG), Politecnico di Torino, Torino, Italy \\ ${ }^{2}$ Department of Regional and Urban Studies and Planning (DIST), Politecnico di Torino, Torino, Italy
}

\begin{abstract}
Nowadays, there is a need for reducing building's energy consumption while preserving a comfortable and healthy indoor environment. After a detailed analysis of the literature in the domain of indoor environmental quality, occupant well-being, health and productivity, the paper explores the relationships between energy retrofit, interventions, indoor comfort and economic benefits and it proposes a real application concerning the case study of a hotel in Turin (Italy). The simulation was carried out through a Cost-Benefit Analysis that allowed to monetize and optimize the economic benefits, in terms of clients' thermal comfort and employees' productivity, while preserving the heating energy costs.
\end{abstract}

\section{Introduction}

Nowadays, the awareness of the close relationship between the Indoor Environmental Quality (IEQ), the occupant's well-being, health and productivity, and the building energy efficiency is gradually growing. Indeed, the European Union Framework Programme for Research and Innovation, Horizon 2020, promoted the development of new funding opportunities on these focus areas in the future scientific researches. Furthermore, the recently approved revision of the European Parliament Building Directive (European Parliament, 2018) underlined the importance to build a comfortable indoor environment, introducing a new Smart Readiness Indicator (SRI) that could contribute to enhancing energy efficiency, comfort and well-being of the occupants. In the present-day, people spend about $80-90 \%$ of their life in enclosed spaces (ASHRAE, 2011) characterized by an indoor air from 2 to 5 times more polluted than outdoors (Wallace, 1987). To guarantee comfortable conditions and to ensure health and performance of building's occupants, it is necessary to monitor, verify and optimize the indoor environmental quality. For this reason, the paper critically shows the results of a literature review aimed at analyzing and evaluating how the IEQ influences health, comfort and productivity of the occupants. It is focused on collecting useful information for both energyenvironmental and economic-financial assessments with regards to thermal comfort in the hospitality sector. The choice to investigate this sector is due to its multifunctionality, characterized by a variety of indoor environments, by different types of users and by high energy consumptions. Indeed, the hotel represents the most energy-intensive sector of the tourism industry, with approximately $50 \%$ of energy consumption due to space conditioning (heating, cooling and ventilation in order to maintain high standards of comfort) (Bohdanowicz and Martinec, 2002).

A field of studies demonstrated that a reduction in the temperature could positively contribute to reduce the energy costs; it has been shown that a $1{ }^{\circ} \mathrm{C}$ decrease in indoor temperature accounts for a $10 \%$ reduction in heating costs (Bohdanowicz and Martinec, 2002). Focusing on thermal comfort, the dissatisfaction with the thermal conditions of the environment represents the most common problem among occupants. Furthermore, since the thermal preference is an extremely personal factor, studies on individual climate control systems were increased in order to maximize the indoor comfort (Arens et al., 1991; Melikov and Nielsen, 1989). Nowadays, the assessments are not only linked to building's energy efficiency but are based on the occupant; it is essential to consider the strong relationship occupant-buildingsystem in order to ensure a better comfort inside building. Indeed, as active users, the occupants interact with the indoor environment in order to improve their comfort conditions. In detail, the paper shows the results of an energy efficiency action based on human interactions with the control of temperature inside the hotel. The simulation was carried out through a Cost-Benefit Analysis (CBA), method used to determine the best temperature setting scenario that allows obtaining benefits while preserving energy savings.

The study was developed using a range of literature review looking at papers, books and using the Standard concerning the IEQ. First, it is essential to identify the main keywords that can give information about the topic of the study. The paper is structured in the following way. Section "Methods" shows the methodology of data collection deriving from a literature review about the different methods of monetization of IEQ with regard to various uses in order to identify the optimal one for the hotel industry. Section "Application" concerns the application of the method, previously identified, to a real hotel building in Turin (Italy); in this section three indoor environments, guest rooms, service areas and common areas, are analysed in order to take into account the economic benefits of both the client and the employee. Finally, the last section describes the results of the economic evaluation on the different temperature setting 
scenarios in order to identify the optimal one, in economic and energy terms that guarantees the best economic benefit to the hotel owner.

\section{Methods}

The research starts from a state-of-the-art literature survey about the different methods of monetization of indoor environmental quality (thermal, visual, acoustic comfort and indoor air quality) for each building's categories (hotel, residence, school and office). Secondly, the case study of the hotel has been considered, estimating the economic benefits related to different energy requalification and interventions, and comparing alternative management scenarios by means of the CostBenefit Analysis (CBA). In particular, the results obtained in the CBA allowed to evaluate the optimal temperature setting scenario in the different hotel areas that both clients and employees should set up in order to maximize their benefits and to reduce the energy consumptions.

\section{Literature Review}

The purpose of this literature review was to identify an economic-financial method to evaluate the indoor comfort in a hotel building. Because of the lack of papers concerning the hospitality sector, the research widens the analysis to different typologies of buildings: hotel, residence, school and office. Table 1 shows the inspected papers divided according to the category previously mentioned. For each of them the authors, the year and the source are specified. Moreover, a review was conducted by Science Direct, Research Gate and Google Scholar as main research platforms.

From the literature analysis, different methods emerged for the various uses; in hotels, the Willingness To Pay (WTP) an extra cost for better comfort conditions in rooms was investigated (Buso et al., 2016; Buso et al., 2017); in residences, the method was based on future energy savings (Fang et al., 2012; Noris et al., 2013; Clinch and Healy, 2003); in schools, the quantification of indoor comfort in monetary terms was evaluated in relation to student's learning and performance (ClementsCroome et al., 2008; Wheeler, 2014); finally, in offices, the economic benefits of improving comfort were estimated quantitatively in relation to employee productivity, reduction from sickness absences, and reduction of Sick Building Syndrome (SBS) symptoms (Brager, 2013; Seppänen et al., 2004; Seppänen and Fisk, 2011). As a result of this review, some criticisms and limitations were made about the literature. All the analysed papers give a monetary quantification of Indoor Air Quality (IAQ) and thermal comfort effects, while the visual and acoustic comfort are evaluated only with a qualitative point of view. For this reason, the paper focuses on estimating the economic benefits in terms of thermal comfort. Lastly, concerning hotels, it was necessary not only to talk about monetization of comfort in relation to the WTP for better environmental conditions in the hotel rooms, but also to take into consideration the working comfort for employees. First because a wider view of the hotel spaces is needed (not focusing only on the rooms quality but also on common and service areas). and secondly because the workers give a $24 \mathrm{~h}$ service to guarantee costumer's satisfaction. From these considerations, the research carries on finding three main areas in hotels:

- guest spaces, which are rooms made up of individual spaces with variable energy loads;

- common areas, consisting of reception, lobby, restaurant, bar, gym and conference room featuring both the clients and the staff;

- service areas, such as laundry, cooking and offices exclusively for employees.

In this context, it was essential to take into account the different requirements of occupants; on one hand, the employees prefer pleasant working conditions to achieve higher productivity and working performances; on the other hand, costumers or guests look for a comfortable indoor environment in hotel rooms and a safe stay.

Moreover, the influence of the thermo-hygrometric microclimate on the occupant's comfort, health and productivity, was amply demonstrated by the literature review. Thermal conditions can affect the performance of work in different ways (Wyon and Wargocki, 2006): (1) thermal discomfort generates complaints and increases maintenance costs; (2) warmth have a negative effect on SBS symptoms and on occupant's concentration (Willem, 2006); (3) cold conditions have a negative effect on manual tasks; (4) vertical thermal gradients lead to a reduction in room temperature.

In the present study, the economic benefits of improving thermal comfort in hotel work environments (service and common areas) were estimated quantitatively in relation to employees' productivity and salary. In order to quantify and monetize the economic benefit carried out from different indoor temperature setting, a field of studies about the effects of the temperature on worker's performance were investigated. Various papers discussed about the strong relationship between air temperature and employees' performance or absenteeism in workplaces. (Wyon, 1996) showed that thermal conditions within the thermal comfort zone can reduce performance by $5 \%$ to $15 \%$. (Niemela et al., 2002) carried out a study in an office building discovering that the average talk-time was $5-7 \%$ lower when temperatures remained below $25^{\circ} \mathrm{C}$. Moreover, in a call-centre the average talk-time of an operator improved by $4.9 \%$ when the air temperature was decreased by $2^{\circ} \mathrm{C}$ from $24.5^{\circ} \mathrm{C}$ (Tham et al., 2003). Another experiment conducted in the laboratory by Witterseh (2004) on 30 subjects engaged in activities that simulated normal office work demonstrated that at temperatures of $22^{\circ} \mathrm{C}, 26^{\circ} \mathrm{C}$ and $30^{\circ} \mathrm{C}$, the percentage of dissatisfied due to perceived air quality was respectively 5\%, 34\% and 88\%. Finally, the studies of Preller (1990) and Raw (1990) in an office building were demonstrated that self-estimated performance was higher when occupants can control their own thermal climate. 
Table 1: Literature review of papers concerning economic and financial valuation of indoor comfort.

\begin{tabular}{|c|c|c|c|c|}
\hline & Title & Author & Year & Source \\
\hline \multirow{6}{*}{ 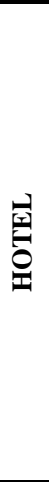 } & $\begin{array}{l}\text { Of comfort and cost: Examining indoor comfort conditions } \\
\text { and guests' valuations in Italian hotel rooms }\end{array}$ & Buso, et al. & 2017 & Energy Res. Soc. Sci., vol. 32 \\
\hline & Thermal comfort and energy savings in the hotel industry & $\begin{array}{l}\text { Bohdanowicz } \\
\text { and Martinec }\end{array}$ & 2002 & $\begin{array}{c}16^{\text {th }} \text { International Society } \\
\text { Conference on Biometeorology }\end{array}$ \\
\hline & $\begin{array}{l}\text { Evaluation of perceived indoor environmental quality of } \\
\text { five-star hotels in China: an application of online review } \\
\text { analysis }\end{array}$ & Qi, et al. & 2017 & Build. Environment, vol. 111 \\
\hline & $\begin{array}{l}\text { Consumers' willingness to pay premium for green hotels: } \\
\text { Fact or Fad? }\end{array}$ & Dimara, et al. & 2015 & $\begin{array}{l}14^{\text {th }} \text { International Marketing } \\
\text { Trends Conference }\end{array}$ \\
\hline & $\begin{array}{c}\text { Energy efficiency and financial performance of a reference } \\
\text { hotel - proposing a global Cost-Benefit Analysis }\end{array}$ & Buso, et al. & 2016 & $12^{\text {th }}$ REHVA World Congress \\
\hline & $\begin{array}{l}\text { Energy savings and guaranteed thermal comfort in hotel } \\
\text { rooms through nonlinear model predictive controllers }\end{array}$ & Acosta, et al. & 2016 & Energy Build., vol. 129 \\
\hline \multirow{3}{*}{ 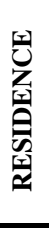 } & $\begin{array}{l}\text { Monetization of thermal comfort in residential buildings } \\
\text { comfort model description }\end{array}$ & Fang, et al. & 2012 & $17^{\text {th }}$ ACEE Conference \\
\hline & $\begin{array}{l}\text { Indoor environmental quality benefits of apartment energy } \\
\text { retrofits }\end{array}$ & Noris et al. & 2013 & Build. Environment, vol. 68 \\
\hline & $\begin{array}{l}\text { Valuing improvements in comfort from domestic energy- } \\
\text { efficiency retrofits using a trade-off simulation model }\end{array}$ & $\begin{array}{l}\text { Clinch and } \\
\text { Healy }\end{array}$ & 2003 & Energy Econ., vol. 25 \\
\hline \multirow{4}{*}{ סृ } & $\begin{array}{c}\text { The sustainable school: effective and energy efficient } \\
\text { ventilation in the classroom, and the question of } \\
\text { educational performance and well-being }\end{array}$ & Wheeler & 2014 & World Conf. Sustain. Build. \\
\hline & Ventilation rates in schools & $\begin{array}{l}\text { Clements- } \\
\text { Croome, et al. }\end{array}$ & 2008 & Build. Environment, vol. 43 \\
\hline & $\begin{array}{l}\text { Daylighting in schools, an investigation into the } \\
\text { relationship between daylight and human performance }\end{array}$ & Heschong & 1999 & $\begin{array}{l}\text { California Board for Energy } \\
\text { Efficiency } \\
\end{array}$ \\
\hline & $\begin{array}{l}\text { Effects of classroom acoustics on performance and well- } \\
\text { being in elementary school children: a field study }\end{array}$ & Klatte, et al. & 2010 & Environ. Behav., vol. 42 \\
\hline \multirow{16}{*}{$\frac{\sqrt[1]{0}}{0}$} & $\begin{array}{l}\text { Proposal for a modified cost-optimal approach by } \\
\text { introducing benefits evaluation }\end{array}$ & Becchio, et al. & 2015 & Energy Procedia, vol. 82 \\
\hline & $\begin{array}{l}\text { Benefits of improving occupant comfort and well-being in } \\
\text { buildings }\end{array}$ & Brager & 2013 & $\begin{array}{l}4^{\text {th }} \text { International Holcim forum } \\
\text { for sustainable construction }\end{array}$ \\
\hline & $\begin{array}{l}\text { Review on visual comfort in office buildings and influence } \\
\text { of daylight in productivity }\end{array}$ & De Carli, et al. & 2008 & $\begin{array}{c}11^{\text {th }} \text { International Conference } \\
\text { on Indoor Air Quality and } \\
\text { Climate } \\
\end{array}$ \\
\hline & Indoor climate and productivity in offices & Wargocki, et al. & 2006 & Rehva Gb, vol. 6 \\
\hline & $\begin{array}{l}\text { Cost-Benefit Analysis of improved air quality in an office } \\
\text { building }\end{array}$ & $\begin{array}{l}\text { Djukanovic, et } \\
\text { al. }\end{array}$ & 2002 & $\begin{array}{l}9^{\text {th }} \text { International Conference on } \\
\text { Indoor Air Quality and Climate }\end{array}$ \\
\hline & $\begin{array}{c}\text { Effect of temperature on task performance in office } \\
\text { environment }\end{array}$ & Seppänen, et al. & 2006 & $\begin{array}{c}5^{\text {th }} \text { International Conference on } \\
\text { Cold Climate HVAC }\end{array}$ \\
\hline & $\begin{array}{c}\text { Control of temperature for health and productivity in } \\
\text { offices }\end{array}$ & Seppänen, et al. & 2005 & ASHRAE Transactions, vol.111 \\
\hline & $\begin{array}{l}\text { A procedure to estimate the cost effectiveness of the indoor } \\
\text { environment improvements in office work }\end{array}$ & $\begin{array}{l}\text { Seppänen and } \\
\text { Fisk } \\
\end{array}$ & $\begin{array}{c}2006 \\
\text { (a) }\end{array}$ & $\begin{array}{l}\text { Creating the productivity } \\
\text { workplace (Book) }\end{array}$ \\
\hline & $\begin{array}{c}\text { Method for cost-benefit analysis of improved indoor } \\
\text { climate conditions and reduced energy consumption in } \\
\text { office buildings }\end{array}$ & Jurelionis, et al. & 2013 & Energies, vol. 6 \\
\hline & Benefits and costs of improved IEQ in U.S. offices & Fisk, et al. & 2011 & Indoor Air, vol. 21 \\
\hline & $\begin{array}{l}\text { Health-related costs of indoor ets, dampness and mold in } \\
\text { the united states and in California }\end{array}$ & Fisk & 2005 & $\begin{array}{l}10^{\text {th }} \text { International Conference } \\
\text { on Indoor Air Quality and } \\
\text { Climate } \\
\end{array}$ \\
\hline & $\begin{array}{c}\text { Some quantitative relations between indoor environmental } \\
\text { quality and work performance or health }\end{array}$ & $\begin{array}{l}\text { Seppänen and } \\
\text { Fisk }\end{array}$ & $\begin{array}{c}2006 \\
(\mathrm{~b})\end{array}$ & HVAC\&R Res., vol. 12 \\
\hline & $\begin{array}{l}\text { Estimate of an economic benefit from investment in } \\
\text { improved indoor air quality in an office building }\end{array}$ & Wargocki & 2003 & $\begin{array}{c}7^{\text {th }} \text { International Conference on } \\
\text { Healthy Buildings }\end{array}$ \\
\hline & Review of health and productivity gains from better IEQ & Fisk & 2000 & $\begin{array}{c}\text { International Conference on } \\
\text { Healthy Buildings }\end{array}$ \\
\hline & $\begin{array}{l}\text { Influence of indoor air temperature variation on office work } \\
\text { performance }\end{array}$ & $\begin{array}{l}\text { Valančius and } \\
\text { Jurelionis }\end{array}$ & 2013 & $\begin{array}{l}\text { J. Environ. Eng. Landsc. } \\
\text { Manag., vol. } 21\end{array}$ \\
\hline & $\begin{array}{l}\text { Providing better indoor environmental quality brings } \\
\text { economic benefit }\end{array}$ & $\begin{array}{l}\text { Fisk and } \\
\text { Seppänen }\end{array}$ & 2007 & $9^{\text {th }}$ REHVA World Congress \\
\hline
\end{tabular}




\section{Cost-Benefit Analysis methodology}

An analysis based on Cost-Benefit Analysis (CBA) approach was proposed in order to identify the optimal temperature setting scenario that allows obtaining benefits while preserving energy savings. According to European Commission (2014), CBA is a systematic approach used in investment decisions in order to assess the welfare changes attributable to alternative projects and to select the most profitable in terms of the society's convenience (Becchio et al., 2018). It is developed through the following five steps: 1) identification of costs and benefits of the project; 2) estimation of the monetary values; 3 ) distribution of the estimated costs and benefits over the time and construction of the cash flow; 4) definition of the discount rate; 5) calculation of the performance indicators.

In the present study, a Benefit-Cost Ratio (BCR) was used to determine the economic efficiency of the different scenarios analysed. The following formula (1) presents the ratio between discounted economic benefits and costs:

$$
\frac{B}{C}=\frac{\sum_{t=1}^{t=n} \frac{B_{t}}{(1+r) t}}{\sum_{t=1}^{t=n} \frac{C_{t}}{(1+r)^{t}}}
$$

where $n$ is the analytic horizon, $t$ represents the cash flow period, $B_{\mathrm{t}}$ is the cash flow of benefits, $\mathrm{C}_{\mathrm{t}}$ is the cash flow of costs, and $r$ is the discount rate.

\section{Application}

The methodological approaches presented in the previous section were applied to an existing building in the centre of Turin (Italy), the Hotel Residence L'Orologio.

The main input data are presented in the Table 2.

Table 2: Input data of the analysis.

\begin{tabular}{|c|c|}
\hline Occupation rate (short-stay) & $25 \%$ (average 2013-2014) \\
\hline $\begin{array}{c}\text { Occupation rate (overnight- } \\
\text { stay > 1 month) }\end{array}$ & $50 \%$ (average 2013-2014) \\
\hline Floors number & 6 \\
\hline Total heated floor area & $1,138 \mathrm{~m}^{2}$ \\
\hline Total heated volume & $3,845 \mathrm{~m}^{3}$ \\
\hline Total rooms surface & $874 \mathrm{~m}^{2}$ \\
\hline Rooms number & 20 \\
\hline Beds number & 78 \\
\hline
\end{tabular}

Three main environments (guest rooms, service areas and common areas) and two different typologies of indoor requirements (by clients and by employees) were identified and discussed in the following sections. This paper was intended to represent a first attempt to monetize the benefits expected from an improvement in indoor thermal conditions considering two different variables. On one hand, the comfort needs of the client were evaluated through the implementation of the questionnaire presented in Buso et al. (2017) in terms of WTP; on the other hand, the needs of the employee by estimating the economic benefits of a comfort improvement based on his productivity. The evaluation was done in relation to the winter season from 15 October to 15 April (182 days), with regard to the heating energy consumption. The economic benefits were quantified in
$€ /\left(\right.$ winter season* $\left.\mathrm{m}^{2}\right)$ and obtained from the difference between the proposed scenario and the state of art (equal to $20^{\circ} \mathrm{C}$ inside the three environments).

\section{Guest rooms}

Monetary evaluation of comfort conditions in guest rooms was estimated by the co-benefits of employing the results coming from a Contingent Valuation Method (CVM) survey concerning the results conducted by Buso et al. (2017). In the survey, the guests were asked the extra price per night they would be willing to pay for better IEQ in the room. The results of the questionnaire have shown that about $18 \%$ (40 people) were not willing to pay an additional price because the room rate per night of 80 $€ /$ night (on average hotel rates in the centre of Turin, Italy) was perceived as enough elevated. The rest of the respondents (184 people) were demonstrated a WTP of about $14 \%$ more than the base room rate. Subsequently, the percentage $(14 \%)$ was applied on the average room price of the Hotel Residence L'Orologio (117 €/night for short-stay and $83 € /$ night for overnight stay), quantifying the guests' willingness to pay as $16.38 € /$ night and 11.62 $€ /$ night more than the base room rate, respectively for short and overnight stay. Finally, considering only the winter season (182 days), the occupation rate in Table 2 and the WTP of clients only for improved the thermal comfort $(25 \%)$, the total WTP an extra cost results equal to $10.31 € /\left(\right.$ winter season* $\left.\mathrm{m}^{2}\right)$. This economic benefit corresponds to an optimum indoor temperature of $22^{\circ} \mathrm{C}$. In Table 3, the economic benefits obtained from the customer's willingness to pay for different temperature settings in the room were summarized.

Table 3: Economic benefits from the guests' WTP in room.

\begin{tabular}{|c|c|c|}
\hline $\begin{array}{c}\text { Temperature } \\
{\left[{ }^{\circ} \mathbf{C}\right]}\end{array}$ & Benefit [\%] & $\begin{array}{c}\Delta \text { Benefit } \\
{[€ /(\text { winter }} \\
\text { season* m²)] }\end{array}$ \\
\hline $21\left(+1^{\circ} \mathrm{C}\right)$ & $\begin{array}{l}10 \% \text { increase in the } \\
\text { room rate }\end{array}$ & 7.36 \\
\hline $22\left(+2^{\circ} \mathrm{C}\right)$ & $\begin{array}{l}14 \% \text { increase in the } \\
\text { room rate }\end{array}$ & 10.31 \\
\hline $23\left(+3^{\circ} \mathrm{C}\right)$ & $\begin{array}{l}10 \% \text { increase in the } \\
\text { room rate }\end{array}$ & 7.36 \\
\hline $19\left(-1^{\circ} \mathrm{C}\right)$ & $\begin{array}{c}-14 \% \text { decrease in the } \\
\text { room rate }\end{array}$ & -10.31 \\
\hline $18\left(-2^{\circ} \mathrm{C}\right)$ & $\begin{array}{l}-14 \% \text { decrease in the } \\
\text { room rate }\end{array}$ & -10.31 \\
\hline $17\left(-3^{\circ} \mathrm{C}\right)$ & $\begin{array}{l}-14 \% \text { decrease in the } \\
\text { room rate }\end{array}$ & -10.31 \\
\hline
\end{tabular}

\section{Service areas}

Hotel Residence L'Orologio service area was represented by a single office $\left(11 \mathrm{~m}^{2}\right)$ occupied by the Director. The estimation of the monthly salary of the employee is acquired by the "Contratto Collettivo Nazionale del Lavoro" (CCNL, 2008) equal to 2,514 €/month (13.6€/h). The study considered that the Director works $8 \mathrm{~h}$ per day, excluding Sunday, reaching a total of 156 working days. Based on these input data, the manager's salary results equal to $16,972 € /$ winter season. Since the workplace was 
characterized by the presence of the employee, quantifying the economic benefits of better thermal comfort was associated with increased productivity. The relation between air temperature and work performance is shown in Figure 1, as follow (2):

$$
\mathrm{RP}_{\mathrm{t}}=0.1647524 \times \mathrm{t}_{\mathrm{c}}-0.0058274 \times \mathrm{t}_{\mathrm{c}}^{2}+0.0000623 \times
$$$$
\mathrm{t}_{\mathrm{c}}^{3}-0.4685328
$$

where $\mathrm{RP}_{\mathrm{t}}$ represents the relative performance and $t_{c}$ is the indoor temperature in ${ }^{\circ} \mathrm{C}$.

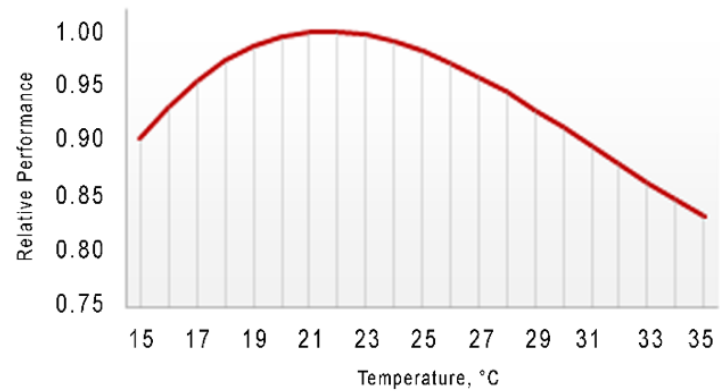

Figure 1: Relative performance in relation to the indoor temperature.

Figure 1 was based on the results from 24 studies, conducted by Seppänen (2006), investigating the effects of temperature on office work performances. The curve suggests that work performance is maximized when the indoor air temperature is about $22^{\circ} \mathrm{C}$. For each variation (increase or decrease) of $1^{\circ} \mathrm{C}$, compared to the optimal temperature $\left(22^{\circ} \mathrm{C}\right)$, a reduction of performance by about $1 \%$ occurs. The economic benefits were obtained from the difference between the proposed scenario and state of the art $\left(20^{\circ} \mathrm{C}\right)$. Table 4 summarizes the economic benefits coming from the various temperature settings in the office.

Table 4: Economic benefits from the various temperature settings in the office.

\begin{tabular}{|c|c|c|}
\hline $\begin{array}{c}\text { Temperature } \\
{\left[{ }^{\circ} \boldsymbol{C}\right]}\end{array}$ & Benefit [\%] & $\begin{array}{c}\Delta \text { Benefit } \\
{[\boldsymbol{\epsilon} /(\text { winter }} \\
\left.\left.\text { season } *^{2}\right)\right]\end{array}$ \\
\hline $21\left(+1^{\circ} \mathrm{C}\right)$ & $\begin{array}{c}0.46 \% \text { increase in } \\
\text { work performance }\end{array}$ & 7.09 \\
\hline $\mathbf{2 2}\left(+\mathbf{2}^{\circ} \mathbf{C}\right)$ & $\begin{array}{c}\mathbf{0 . 5 1 \%} \text { increase in } \\
\text { work performance }\end{array}$ & $\mathbf{7 . 8 6}$ \\
\hline $23\left(+3^{\circ} \mathrm{C}\right)$ & $\begin{array}{c}0.23 \% \text { increase in } \\
\text { work performance }\end{array}$ & 3.54 \\
\hline $19\left(-1^{\circ} \mathrm{C}\right)$ & $\begin{array}{c}0.9 \% \text { decrease in } \\
\text { work performance }\end{array}$ & -13.88 \\
\hline $18\left(-2^{\circ} \mathrm{C}\right)$ & $\begin{array}{c}2.2 \% \text { decrease in } \\
\text { work performance }\end{array}$ & -33.94 \\
\hline $17\left(-3^{\circ} \mathrm{C}\right)$ & $\begin{array}{c}4 \% \text { decrease in work } \\
\text { performance }\end{array}$ & -61.71 \\
\hline
\end{tabular}

(*) Employee salary $=16,972 € /$ winter season $=\mathbf{1 , 5 4 2}$ $\boldsymbol{\epsilon} /\left(\right.$ winter season* $\left.\mathbf{m}^{2}\right)$

\section{Common areas}

The common area of Hotel Residence L'Orologio was represented by the reception $\left(16 \mathrm{~m}^{2}\right)$ on the ground floor and occupied by two employees, the receptionists.

The estimation of the monthly salary of an individual employee is acquired by the CCNL (2008) equal to $16,180 € /$ month $(8.79 € / \mathrm{h})$. The study considered that the employee works $6 \mathrm{~h}$ per day, excluding Sunday, reaching a total of 156 working days (the receptionist's salary was $8,227 €$ /winter season). Table 5 summarizes the economic benefits coming from the various temperature settings in the reception.

Table 5: Economic benefits from different temperature settings in the reception.

\begin{tabular}{|c|c|c|}
\hline $\begin{array}{c}\text { Temperature } \\
{\left[{ }^{\circ} \mathrm{C}\right]}\end{array}$ & Benefit [\%] & $\begin{array}{c}\Delta \text { Benefit } \\
{[E /(\text { winter }} \\
\left.\left.\text { season } * m^{2}\right)\right]\end{array}$ \\
\hline $21\left(+1^{\circ} \mathrm{C}\right)$ & $\begin{array}{l}0.46 \% \text { increase in } \\
\text { work performance }\end{array}$ & 4.73 \\
\hline $22\left(+2^{\circ} \mathrm{C}\right)$ & $\begin{array}{l}0.51 \% \text { increase in } \\
\text { work performance }\end{array}$ & 5.24 \\
\hline $23\left(+3^{\circ} \mathrm{C}\right)$ & $\begin{array}{l}0.23 \% \text { increase in } \\
\text { work performance }\end{array}$ & 2.36 \\
\hline $19\left(-1^{\circ} \mathrm{C}\right)$ & $\begin{array}{l}0.9 \% \text { decrease in } \\
\text { work performance }\end{array}$ & -9.20 \\
\hline $18\left(-2^{\circ} \mathrm{C}\right)$ & $\begin{array}{l}2.2 \% \text { decrease in } \\
\text { work performance }\end{array}$ & -22.62 \\
\hline $17\left(-3^{\circ} \mathrm{C}\right)$ & $\begin{array}{l}4 \% \text { decrease in } \\
\text { work performance }\end{array}$ & -41.13 \\
\hline
\end{tabular}

(*) Employee salary $=8,227 € /$ winter season $=514$

$€ /\left(\right.$ winter season* $\left.\mathrm{m}^{2}\right)$. Two employees: $\mathbf{1 , 0 2 8} € /($ winter season* $\mathbf{m}^{2}$ )

The approach used to evaluate the economic benefits was the same for the service areas presented in the previous section. In this case, in order to obtain a correct evaluation of the reception area it was necessary to consider the presence of clients. Based on the hypothesis that the client went through the reception about 4 times a day and the average of his/her stay was 10 minutes, the customer's Willingness To Pay for better comfort conditions in the reception was equal to $1.16 € /\left(\right.$ winter season* ${ }^{2}$ ) associated with an optimal indoor temperature of $21^{\circ} \mathrm{C}$.

\section{Energy consumption and costs}

In order to monetize the energy consumption, a quantification was necessary, which in the present study required an energy simulation that refers to the Energy Audit Report (SiTI, 2015). The total energy consumption $\left(97.46 \mathrm{kWh} /\left(\right.\right.$ winter season* $\left.\mathrm{m}^{2}\right)$ and the equivalent energy costs $\left(6.32 € /\left(\right.\right.$ winter season* $\left.\mathrm{m}^{2}\right)$ of the Hotel Residence L'Orologio were referred to the only winter season and therefore to the heating consumption of the building, considering the state of art of $20^{\circ} \mathrm{C}$. Table 6 shows the economic benefits for different temperature scenarios $\left( \pm 3^{\circ} \mathrm{C}\right)$ for power consumption/energy savings. Each upward (or downward) variation of $1{ }^{\circ} \mathrm{C}$ of temperature with respect to the state of art $\left(20^{\circ} \mathrm{C}\right)$ results into a $7 \%$ increase (or decrease) of the energy cost. The 
economic benefits were quantified in $€ /$ (winter season* $\mathrm{m}^{2}$ ) and obtained from the difference between the energy costs of the proposed scenario and the energy costs of state of the art $\left(6.32 € /\left(\right.\right.$ winter season* $\left.\mathrm{m}^{2}\right)$.

Table 6: Economic benefits in terms of energy for different temperature settings.

\begin{tabular}{|c|c|c|}
\hline $\begin{array}{c}\text { Temperature } \\
{\left[{ }^{\circ} \boldsymbol{C}\right]}\end{array}$ & Benefit [\%] & $\begin{array}{c}\Delta \text { Benefit } \\
{[\boldsymbol{\epsilon} /(\text { winter }} \\
\left.\left.\text { season*m }{ }^{2}\right)\right]\end{array}$ \\
\hline $21\left(+1^{\circ} \mathrm{C}\right)$ & $\begin{array}{c}7 \% \text { increase in } \\
\text { energy costs }\end{array}$ & 0.44 \\
\hline $22\left(+2^{\circ} \mathrm{C}\right)$ & $\begin{array}{c}14 \% \text { increase in } \\
\text { energy costs }\end{array}$ & 0.88 \\
\hline $23\left(+3^{\circ} \mathrm{C}\right)$ & $\begin{array}{c}21 \% \text { increase in } \\
\text { energy costs }\end{array}$ & 1.32 \\
\hline $19\left(-1^{\circ} \mathrm{C}\right)$ & $\begin{array}{c}7 \% \text { decrease in } \\
\text { energy costs }\end{array}$ & -0.44 \\
\hline $18\left(-2^{\circ} \mathrm{C}\right)$ & $\begin{array}{c}14 \% \text { decrease in } \\
\text { energy costs }\end{array}$ & -0.88 \\
\hline $17\left(-3^{\circ} \mathrm{C}\right)$ & $\begin{array}{c}21 \% \text { decrease in } \\
\text { energy costs }\end{array}$ & -1.32 \\
\hline
\end{tabular}

\section{Results and discussion}

The following section identifies all the indoor temperature settings combined for the three distinct areas: guest rooms, office and reception. The different scenarios were assumed for all temperature combinations, excluding those at $17^{\circ} \mathrm{C}$ and $18^{\circ} \mathrm{C}$ because, for the winter reference season, they are outside from $\mathrm{PPD}=10 \%$. Therefore, the temperature setting considered are $19^{\circ} \mathrm{C}$, and from $21^{\circ} \mathrm{C}$ to $23^{\circ} \mathrm{C}$; as a consequence, there were 64 possible scenarios. For each of them, the energy cost and the overall economic benefit in terms of $€$ /winter season were calculated. The evaluation of the relationship between benefits and costs will allow to identify the optimal scenario represented in Table 7 and characterized by a temperature inside the three environments equal to $21^{\circ} \mathrm{C}$.

Table 7: Scenario $21^{\circ} \mathrm{C}-21^{\circ} \mathrm{C}-21^{\circ} \mathrm{C}$.

\begin{tabular}{|c|c|c|c|}
\hline & & {$[€ /($ winter season $]$} & \\
\hline \multirow{4}{*}{$\frac{n}{0}$} & Office & 4.84 & \\
\hline & Reception & 7.04 & \\
\hline & Rooms & 384.56 & \\
\hline & TOT & 396.44 & \\
\hline \multirow{4}{*}{ 串 } & Office & 77.99 & \\
\hline & Reception & 94.24 & \\
\hline & Rooms & $4,824.48$ & \\
\hline & TOT & $4,996.71$ & \\
\hline \multicolumn{3}{|c|}{ Benefits/Costs Ratio (BCR) } & 12.60 \\
\hline
\end{tabular}

As shown in the Table 7 , the setting of $21^{\circ} \mathrm{C}$ in office, reception and guest rooms correspond to a BCR of 12.60. In this scenario, the ratio between benefits and costs was maximized. It is possible to notice that while not reaching the optimal set-point of $22^{\circ} \mathrm{C}$ the benefits were optimized at the indoor temperature of $21^{\circ} \mathrm{C}$; as a matter of fact, despite the overall economic benefit of the presented scenario was lower than that of the scenario at $22^{\circ} \mathrm{C}$, the costs related to energy consumption for heating were much lower.
Table 8 shows the scenario at the set-point temperature of $22^{\circ} \mathrm{C}$ in all environments; this temperature guarantees the maximum benefit from both the customer, who was Willing To Pay $14 \%$ more on the price of the room, and the employee, who maximizes his/her work performance.

Table 8: Scenario $22^{\circ} \mathrm{C}-22^{\circ} \mathrm{C}-22^{\circ} \mathrm{C}$.

\begin{tabular}{|c|c|c|c|}
\hline & & {$[€ /$ (winter season] } & \\
\hline \multirow{4}{*}{$\stackrel{n}{\tilde{\theta}}$} & Office & 9.68 & \\
\hline & Reception & 14.08 & \\
\hline & Rooms & 769.12 & \\
\hline & TOT & 792.88 & \\
\hline \multirow{4}{*}{ 胥 } & Office & 86.46 & \\
\hline & Reception & 96.96 & \\
\hline & Rooms & $6,758.20$ & \\
\hline & TOT & $6,941.62$ & \\
\hline \multicolumn{3}{|c|}{ Benefits/Costs Ratio (BCR) } & 8.75 \\
\hline
\end{tabular}

As shown in Table 8 , the temperature scenario of $22^{\circ} \mathrm{C}$ corresponds to a cost-benefit ratio of 8.75 ; this result is lower than the scenario above (Table 7) despite representing the optimal set-point temperature in terms of expected economic benefits. As a matter of fact, it can be seen that the total benefits are much higher, but at the same time, the $2^{\circ} \mathrm{C}$ increase of the temperature (with respect to the state of art of $20^{\circ} \mathrm{C}$ ) results in the improvement of heating energy.

\section{Conclusion}

The research work gave the possibility to identify the optimal method of monetization of thermal comfort in the hotel sector. This paper represents a first attempt to monetize the benefits expected from an improvement in indoor comfort conditions through the analysis of two variables: on one hand, the comfort needs of the client were evaluated by an implementation of the results obtained from Buso et al. (2017) in terms of Willingness To Pay, on the other hand the needs of the employee by estimating the economic benefits of a comfort improvement based on his productivity. The final objective was to identify, through a CBA, the optimal scenario that guarantees the best economic benefit to the hotel owner. The results of the analysis showed that the optimal scenario was identified at a temperature of $21^{\circ} \mathrm{C}$ inside all three considered areas, which corresponds to a benefit-cost ratio of 12.60; these conditions allow to maximize the thermal comfort in relation to a high energy saving for heating. The application to the case study concerned the hotel sector but the approach identified can be applied to different uses (Becchio et al., 2019). Furthermore, it is necessary to underline that the analysis was exclusively about the evaluation of thermal comfort. For this reason, it would be interesting to investigate on visual and acoustic comfort, and indoor air quality in order to give a complete view of the benefits deriving from the improvement of the indoor environmental conditions. 


\section{References}

Acosta, A., Gonzale, A.I., Zamarreño, J.M., Álvarez, V. (2016). Energy savings and guaranteed thermal comfort in hotel rooms through nonlinear model predictive controllers. Energy \& Buildings 129, 59-68.

Arens, E.A., Bauman, F.S., Johnston, L.P., Zhang, H. (1991). Testing of localized ventilation systems in a new controlled-environment chamber. Indoor Air 1(3), 263-281.

ASHRAE (2011). Guideline 10 - Interactions Affecting the Achievement of Acceptable Indoor Environments. American Society of Heating, Refrigerating, and Air Conditioning Engineers. Atlanta (GA).

Bateman, I., Carson, R., Day, B., Hanemann, M., Hanley, N., Hett, T., Jones-Lee, M., Loomes, G., Mourato, S., Ozdemiroglu, E., Pearce, D., Sugden, J., Swanson, J. (2002). Economic Valuation with Stated Preference Techniques: A Manual. Edward Elgar. Cheltenham (UK).

Becchio, C., Corgnati, S.P., Orlietti, L., Spigliantini, G. (2015). Proposal for a modified cost-optimal approach by introducing benefits evaluation. Energy Procedia $82,445-451$.

Becchio, C., Bottero. M.C., Corgnati, S.P., Dell'Anna, F., (2018). Decision making for sustainable urban energy planning: an integrated evaluation framework of alternative solutions for a NZED in Turin. Land Use Policy 78, 803-817.

Becchio, C., Bertoncini, M., Boggio, A., Bottero, M., Corgnati, S., Dell'Anna, F. (2019). The impact of users' lifestyle in zero-energy and emission buildings: an application of cost-benefit analysis. In Calabrò F., Della Spina, L., Bevilacqua C. New Metropolitan Perspectives. Springer. Cham (DE).

Bohdanowicz, P. and Martinac, I.M. (2002). Thermal comfort and energy saving in the hotel industry. Proceedings from 15th Conference on Biometeorology and Aerobiology \& $16^{\text {th }}$ International Congress on Biometeorology. Kansas City (USA), 28 October-1 November 2002.

Brager, G.S. (2013). Benefits of improving occupant comfort and well-being in buildings. Proceedings from the $4^{\text {th }}$ International Holcim forum for sustainable construction. Mumbai (IND), 11-13 April 2013.

Buso, T., Becchio, C., Corgnati, S.P., Yilmaz, Z.A. (2016). Energy efficiency and financial performance of a reference hotel: proposing a global Cost-Benefit Analysis. Proceedings from Clima 2016: $12^{\text {th }}$ REHVA World Congress. Aalborg (DK), 22-25 May 2016.

Buso, T., Dell'Anna, F., Becchio, C., Bottero, M.C., Corgnati, S.P. (2017). Of comfort and cost: Examining indoor comfort conditions and guests' valuations in Italian hotel rooms. Energy Research \& Social Science 32, 94-111.
Clements-Croome, D.J., Awbi, H.B., Bakó-Biró, Z., Kochhar, N., Williams, M. (2008). Ventilation rates in schools. Building and Environment 43(3), 362-367.

Clinch, J.P., and Healy, J.D. (2003). Valuing improvements in comfort from domestic energyefficiency retrofits using a trade-off simulation model. Energy Economics 25(5), 565-583.

Contratto Collettivo Nazionale di Lavoro (CCNL) per i dipendenti delle Aziende del settore Alberghi, Ristoranti, Bar e Mense (2008).

De Carli, M., De Giuli, V., Zecchin, R. (2008). Review on visual comfort in office buildings and influence of daylight in productivity. Proceedings from Indoor Air 2008: $11^{\text {th }}$ International Conference on Indoor Air Quality and Climate. Copenhagen (DK), 17-22 August 2008.

Dimara, E., Manganari, E., Skuras, D. (2015). Consumers' willingness to pay premium for green hotels: Fact or Fad? Proceedings from IMTC 2015: $14^{\text {th }}$ International Marketing Trends Conference 2015. Paris (FR), 22-24 January 2015.

Djukanovic, R., Wargocki, P., Fanger, P.O. (2002). CostBenefit Analysis of improved air quality in an office building. Proceedings from Indoor Air 2002: $9^{\text {th }}$ International Conference on Indoor Air Quality and Climate. Monterey (CA), 30 June-5 July 2002.

European Commission (2014). Guide to Cost-Benefit Analysis of Investment Projects: Structural Funds, Cohesion Fund and Instrument for Pre-Accession, Directorate-General for Regional Policy.

European Parliament (2013). Regulation 1291/2013 of the European Parliament and of the Council of 11 December 2013 on the Research and Innovation Programme (2014-2020) - Horizon 2020.

European Parliament (2018). Directive 2018/844/EU of the European Parliament and of the Council of 30 May 2018 amending Directive 2010/31/EU on the energy performance of buildings and the directive 2012/27/EU on energy efficiency.

Fang, X., Bianchi, M.V., Christensen, C. (2012). Monetization of thermal comfort in residential buildings comfort model description. Proceedings from 2012 ACEE Summer Study: 17 $7^{\text {th }}$ biennial ACEEE conference on Energy Efficiency in Buildings. Pacific Grove (CA), 12-17 August 2012.

Fisk, W. (2000). Review of health and productivity gains from better IEQ. Proceedings from Healthy Buildings 2000. Espoo (FI), 6-10 August 2000.

Fisk, W. (2005). Health-related costs of indoor ets, dampness and mold in the United States and in California. Proceedings from Indoor Air 2005:10 th International Conference on Indoor Air Quality and Climate. Beijing (CHN), 4-9 September 2005.

Fisk, W., and Seppänen, O. (2007). Providing better indoor environmental quality brings economic benefit. Proceedings from Clima 2007: $9^{\text {th }}$ REHVA 
World Congress for Building Technologies. Helsinki (FI), 10-14 June 2007.

Fisk, W., Black, D., Brunner, G. (2011). Benefits and costs of improved IEQ in U.S. offices. Indoor Air 21(5), 357-367.

Heschong, L. (1999). Daylighting in schools: an investigation into the relationship between daylight and human performance. Detailed Report. Pacific Gas and Electric Company. Fair Oaks (CA).

Istituto Superiore sui Sistemi Territoriali per l'Innovazione (2015). Relazione di audit energetico. Progetto Europee neZEH.

Jurelionis, A., Valančius, R., Doroševas, V. (2013). Method for cost-benefit analysis of improved indoor climate conditions and reduced energy consumption in office buildings. Energies 6(9), 4591-4606.

Klatte, M., Hellbrück, J., Seidel, J., Leistner, P. (2010). Effects of classroom acoustics on performance and well-being in elementary school children: A field study. Environment and Behavior 42(5), 659-692.

Melikov, A.K. and Nielsen, J.B. (1989). Local thermal discomfort due to draft and vertical temperature difference in rooms with displacement ventilation. ASHRAE Transactions 95(2), 1050-1057.

Niemela, R., Hannula, M., Rutio, S., Reijula, K., Railio, J. (2002). The effect of air temperature on labour productivity in call centres - a case study. Energy and Buildings 34(8), 759-764.

Noris, F., Adamkiewicz, G., Delp, W., Hotchi, T., Russell, M., Singer, B.C., Spears, M., Vermeer, K., Fisk, W.J. (2013). Indoor environmental quality benefits of apartment energy retrofits. Building and Environment 68, 170-178.

Preller, L., Zweers, T., Brunekreef, B., and Boleij, J.S.M. (1990). Sick leave due to work-related health complains among office workers in the Netherlands. Proceedings from Indoor Air'90: $5^{\text {th }}$ International Conference on Indoor Air Quality and Climate. Toronto (CA), 29 July-3August 1990.

Qi, M., Li, X., Zhu, E., Shi, Y. (2017). Evaluation of perceived indoor environmental quality of five-star hotels in China: an application of online review analysis. Building and Environment 111, 1-9.

Raw, G., Roys, M.S., Leaman, A. (1990). Further findings from the office environment survey: Productivity. Proceedings from Indoor Air'90: $5^{\text {th }}$ International Conference on Indoor Air Quality and Climate. Toronto (CA), 29 July-3August 1990.

Seppänen, O., Fisk, W., Faulkner, D. (2005). Control of temperature for health and productivity in offices. ASHRAE Transactions 111(2), 680-686.

Seppänen, O. and Fisk, W. (2006a). A procedure to estimate the cost effectiveness of the indoor environment improvements in office work. In Clements-Croome D. Creating the Productive Workplace. Taylor \& Francis. London (UK).
Seppänen, O. and Fisk, W. (2006b). Some quantitative relations between indoor environmental quality and work performance or health. HVAC\&R Research 12(4), 957-973.

Seppänen, O., Fisk, W., Lei, Q.H. (2006). Effect of temperature on task performance in office environment. Proceedings from $5^{\text {th }}$ International Conference on Cold Climate Heating, Ventilating, and Air Conditioning. Moscow (RU), 21-24 May 2006.

Valančius, R. and Jurelionis, A. (2013). Influence of indoor air temperature variation on office work performance. Journal of Environmental Engineering and Landscape Management 21(1), 19-25.

Wallace, L.A. (1987). The total exposure assessment methodology study: Summary and analysis. Office of Research and Development, U.S. Environmental Protection Agency. United States (US).

Wargocki, P. (2003). Estimate of an economic benefit from investment in improved indoor air quality in an office building. Proceedings from $7^{\text {th }}$ International Conference on Healthy Buildings 2003. Singapore (SG), 7-11 December 2003.

Wargocki, P., Seppänen, O., Andersson, J., Boerstra, A., Clements-Croome, D., Fitzner, K., Hannsen, S. (2006). Indoor climate and productivity in offices: How to integrate productivity in life cycle costs analysis of building services. Rehva, 2006. Brussels (BE).

Wheeler, A.S. (2014). The sustainable school: effective and energy efficient ventilation in the classroom, and the question of educational performance and wellbeing. Proceedings from World Sustainable Building Conference. Barcelona (ES), 28-29 October 2014.

Willem, H.C. (2006). Thermal and indoor air quality effects on physiological responses, perception and performance of tropically acclimatized people. $\mathrm{PhD}$ dissertation at National University of Singapore.

Witterseh, T., Wyon, D.P., Clausen, G. (2004). The effects of moderate heat stress and open-plan office noise distraction on SBS symptoms and on the performance of office work. Indoor Air 14(8), 30-40.

Wyon, D.P (1996). Indoor environmental effects on productivity. Proceedings from IAQ'96: Paths to Better Building Environments. Baltimore (MD), 6-7 October 1996.

Wyon, D.P. and Wargocki, P. (2003). Temperature and ventilation effects on the work performance of office workers: study of call-centre in the tropics. Proceedings from $7^{\text {th }}$ International Conference on Healthy Buildings 2003. Singapore (SG), 7-11 December 2003.

Wyon, D.P. and Wargocki, P. (2006). Room temperature effects on office work. In Clements-Croome D. Creating the Productive Workplace. Taylor \& Francis. London (UK). 